\title{
INDICATION OF CAESAREAN SECTION OPERATION IN PRETERM PREGNANCY AND ITS OUTCOME - A STUDY OF 100 CASES
}

\author{
WAZED $\mathrm{F}^{1}$, JAHAN $\mathrm{S}^{2}$, TANIRA $\mathrm{S}^{3}$
}

\begin{abstract}
:
A prospective study of 100 cases of preterm pregnancy was done in the Department of Obstetrics \& Gynaecology of Dhaka Medical College Hospital and Mitford Hospital, Dhaka from September 2002 to August 2003. The incidence and indications for caesarean section operation were eclampsia 24\%, preeclampsia 20\%, antepartum haemorrhage (APH) 15\%, premature rupture of membrane (PROM) 8\%, PROM with chorioamnionitis 4\%, preterm labour with previous caesarean section $9 \%$, foetal distress with labour pain $7 \%$, less foetal movement $6 \%$, malpresentation with cord prolapse 3\%, multiple pregnancy $2 \%$ and diabetes mellitus with polyhydramnios 2\%. Emergency caesarean section was done in 98 cases and elective operation in 2 cases. Live birth was 93\% and perinatal mortality was 32\%. Neonatal morbiditites were prematurity and birth asphyxia. Maternal mortality in preterm caesarean section was $16 \%$.
\end{abstract}

Key words: Preterm pregnancy, Caesarean section, Indication, Outcome.

J Dhaka Med Coll. 2009; 18(2) : 124-126

\section{Introduction:}

Preterm pregnancy is described as the time period of pregnancy from the age of viability of the foetus (in UK, as 24 completed weeks of gestational age from the data of the last menstrual cycle or 22 completed weeks from the date of conception if that is accurately known) until the completion of 37 weeks of gestation $^{1}$. Though the lower limit of gestation is not uniformly defined, in developed countries it is 24 weeks and in developing countries (e.g. India, Bangladesh) 28 weeks $^{2}$. There has been increased incidence of caesarean section during last two decades to decades to extent from about 5\% to more than 20\% amongst hospital delivery. Thus incidence depends on the different indications, which is now diagnosed and detected early and reduces the fetal and maternal morbidity and morality ${ }^{3}$.

\section{Methods:}

A prospective study of 100 cases of preterm pregnancy was done in the Department of
Obstetrics \& Gynaecology of Dhaka Medical College Hospital and Mitford Hospital, Dhaka from September 2002 to August 2003. Patients who presented with complicated pregnancy before 37 weeks of gestation in the Inpatient department in the hospital were taken as study unit. Both quantitative and qualitative data were collected. On admission, a detailed history of the illness was taken from the patient, thorough general \& systemic examination was done, and findings of the performed investigations were recorded, relevant associated medical conditions were recorded carefully, operative outcome and both preoperative and postoperative complications were recorded and noted from hospital records from patients' file. The babies' notes were also recorded for the study. The data were compiled and analyzed in a tabulated form.

\section{Results:}

The results of the study are shown in tabulated form (Table-I, II, III, IV).

1. Assistant Professor, Department of Obstetrics \& Gynaecology, Dhaka Medical College \& Hospital, Dhaka.

2. Ex-Professor, Department of Obstetrics \& Gynaecology, BSMMU, Dhaka.

3. Coordinator (Health), MCH-FP Clinic, Manabik Shahajya Sangstha (MSS), Dhaka.

Correspondence: Dr. Feroza Wazed. 
Table-I

Incidence and indications of preterm caesarean section ( $n=100$ )

\begin{tabular}{lc}
\hline Incidence/Indication & No. of cases \\
\hline Eclampsia & 24 \\
Preeclampsia & 20 \\
Antepertum haemorrhage (APH) & 15 \\
Premature rupture of membrane (PROM) & 8 \\
PROM with chorioamnionitis & 4 \\
Preterm labour with previous LUCS & 9 \\
Foetal distress with labour pain & 7 \\
Less foetal movement & 6 \\
Malpresentation with cord prolapse & 3 \\
Multiple pregnancy & 2 \\
Diabetes mellitus with polyhydramnios & 2 \\
\hline
\end{tabular}

Table-II

Perinatal outcome in preterm caesarean section

\begin{tabular}{lc}
\hline Perinatal outcome & No. of infants \\
\hline Alive & 81 \\
Still birth & 7 \\
Neonatal death & 25 \\
\hline
\end{tabular}

Table-III

Maternal complications in preterm caesarean section

\begin{tabular}{lc}
\hline Complications & No. of cases \\
\hline No complication & 50 \\
Pulmonary oedema & 17 \\
Postpartum haemorrhage & 4 \\
Wound infection & 10 \\
Urinary tract infection & 3 \\
Death & 16 \\
\hline
\end{tabular}

Table-IV

Foetal complications in pre term caesarean section

\begin{tabular}{lc}
\hline Foetal complications & No. of cases \\
\hline No complication & 10 \\
Intrauterine growth retardation & 15 \\
(IUGR) & \\
Asphyxia & 19 \\
Prematurity & 37 \\
Neonatal death & 12 \\
Stillbirth & 7 \\
\hline
\end{tabular}

\section{Discussion:}

Preterm infants tolerate hypoxia more poorly then at term and significant damage could be prevented by timely intervention at the early sign of foetal distress ${ }^{3}$. Caesarean section is a powerful intervention and often seems to parents as obviously offering the best change to a vulnerable preterm baby ${ }^{4}$. Preterm breech probably benefits to some extent from caesarean section ${ }^{5}$. The incidence of caesarean section has been reported differently depending upon the type of hospital or teaching institute in the world. The caesarean section rate in USA is $15 \%$ in 1978 and $17 \%$ in $1981^{6}$. In Britain, the section rate is $8 \%$ in $1980^{7}$. In Australia, the average rate is $12 \%^{8}$. There is no comprehensive and extensive study in our country on caesarean section, though it is being increasingly employed in all hospitals. So the incidence of preterm caesarean section in Bangladesh is yet to determine. Hospitals of different medical colleges receive a good number of high-risk patients with inadequate or no antenatal care. In the present study, only preterm pregnancy cases were observed. Actually, our aim should be to continue the pregnancy up to term but due to unavoidable circumstances and for saving the life of the mother or foetus, an interventional procedure i.e. caesarean section has to be employed immediately ${ }^{9}$. Nature of caesarean section in the study revealed that emergency caesarean section was done in $98 \%$ in comparison to $2 \%$ of elective caesarean section. This study is comparable to study performed in Scotland during $1994^{7}$.

\section{Conclusion:}

By the preterm caesarean section, we are still unable to reduce the maternal and perinatal loss in general. Careful approach is needed for selecting cases for primary as well as repeated caeserean section. Illiteracy and ignorance are major causes of maternal mortality and morbidity in our country which should be reduced by increasing awareness and motivation. Further studies with larger samples and in different hospitals may reflect the actual incidence of caesarean section both in routine and emergency cases. Moreover, 
hospital record keeping system should be computerized and have a back up.

\section{Acknowledgement:}

We would like to express our gratitude to the participants of the study and the authorities of Dhaka Medical College Hospital and Mitford Hospital, Dhaka for their kind permission to carry out the study.

\section{References:}

1. Dewhursts KE. Dewhursts' textbook of obstetrics and gynaecology for postgraduates. $6^{\text {th }}$ ed. London: 1999. p.291.

2. Bhatla N. ed. Jeffcoate's principles of gynaecology. $6^{\text {th }}$ ed. London: Arnold; 2001. p.24-30.

3. Arias F. ed. Practical guide to high risk pregnancy and delivery. $2^{\text {nd }}$ ed. New York: Mosby; 1994. p.186-7.
4. Gupta V, Kanti R. Review of caesarean section. J Obstet Gynecol India. 1981; 31(1): 30-40.

5. Nassar AH, Adra AM, Chakhtoura N, Gomez-Marin O, Beydoun S. Severe preeclampsia remote from term: labor induction or elective cesarean delivery? Am J Obstet Gynecol. 1998; 179: 1210-3.

6. Wilkinson C, Mclllwaine G, Boulton-Jones C, Cole $\mathrm{S}$. Is a rising caesarean section rate inevitable? Br J Obstet Gynaecol. 1998; 105(1): 45-52.

7. Savage W, Francome C. British caesarean section rates: have we reached a plateau? $\mathrm{Br} \mathrm{J}$ Obstet Gynaecol. 1993; 100(5): 493-6.

8. Luan JQ. The treatment of eclampsia by early interruption of pregnancy: a 15-year review. Asia Oceania J Obstet Gynaecol. 1989; 15(1): 33-5.

9. World Health Organization. The hypertension disorders of pregnancy. WHO Technical Report Series No.758. Geneva, Switzerland. World Health Organization, 1987. 